\title{
Pacing Inadequately
}

National Cancer Institute

\section{Source}

National Cancer Institute. Pacing Inadequately. NCI Thesaurus. Code C63097.

Pacing voltage or pulse width is less than desired. 